\title{
Early Postnatal and Preschool-Age Infection by Fasciola spp.: Report of Five Cases from Vietnam and Worldwide Review
}

\author{
Nguyen Van De, ${ }^{1}$ Thanh Hoa Le, ${ }^{2}$ Veronica H. Agramunt, ${ }^{3}$ and Santiago Mas-Coma ${ }^{3 *}$ \\ ${ }^{1}$ Department of Parasitology, Hanoi Medical University, Hanoi, Vietnam; ${ }^{2}$ Department of Immunology, Institute of Biotechnology, Vietnam \\ Academy of Science and Technology, Hanoi, Vietnam; ${ }^{3}$ Departamento de Parasitología, Facultad de Farmacia, Universidad de
} Valencia, Valencia, Spain

\begin{abstract}
Fascioliasis is reported in five Vietnamese children aged 4 years or younger. A 10-month-old girl child and a 12-month-old boy child are the youngest patients ever diagnosed. Eggs in stools suggested an infection occurred at 5-6 months and 7-8 months of age, respectively. DNA sequencing and egg size indicated this to be the first report of a verified Fasciola gigantica infection in so small children. No specific diagnosis could be obtained in two 3-year-old children detected in the acute phase. A big and gravid ectopic F. gigantica-like worm was surgically found in a 4-year-old boy presenting with peritonitis. A worldwide review showed only 38 past cases in preschool children. They included $3,7,12$, and 16 cases of $1,2,3$, and 4 years, respectively, with a faster infection increase in males from 2 years onward. Reports were from all continents, except Oceania, including severe complications and death. The causal agent, when specifically diagnosed, was always Fasciola hepatica. Analyses include detection in hospital, surveys, and family outbreaks; infection sources; disease phases; parasite burden; ectopic cases; symptom onset; eosinophilia; biochemical markers; and clinical complications. C-reactive protein, creatinine, and y-glutamyl transferase are the most useful biomarkers. A serological test and a coprological analysis are recommended for so small children, in which typical symptoms may be overlooked. Treatment problems were described with many drugs, except triclabendazole. Triclabendazole should be considered the drug of choice for such small children. The possibility of a very early infection by Fasciola spp. should be henceforth considered.
\end{abstract}

\section{INTRODUCTION}

Fluke diseases are included in the groups of schistosomiases and food-borne trematodiases among the list of neglected tropical diseases by the WHO. ${ }^{1}$ At present, these snail-borne helminthiases are in the spotlight because of the climate and global change impacts on these diseases, from geographical spread, ${ }^{2}$ outbreaks, and transmission seasonality modifications $^{3}$ up to prevalence and intensity alterations. ${ }^{4}$

Fascioliasis is highlighted because of its almost worldwide distribution ${ }^{5}$ and potential extreme pathogenicity. ${ }^{6}$ This zoonotic disease is caused by two liver fluke species: Fasciola hepatica in Europe, Africa, Asia, the Americas, and Oceania, and Fasciola gigantica restricted to Africa and Asia. ${ }^{5}$ Fasciola species are transmitted by specific freshwater lymnaeid snails with a marked amphibious behavior which underlies its pronounced susceptibility to climate changes. ${ }^{7}$ Clinically, it presents two disease phases: 1) an initial 3- to 4-month-long invasive or acute phase corresponding to the migration of the excysted, 250- $\mu \mathrm{m}$-long infective juveniles through the intestine wall, abdominal cavity, and liver parenchyma until finally penetrating into the bile ducts, a highly symptomatic phase during which the infection may be detected serologically but not coprologically; and 2) a biliary or chronic phase corresponding to the parasitization by fluke adults in the biliary ducts and gallbladder, which may last up to 13.5 years and is characterized by fluke egg detection in stools. ${ }^{8}$

Of veterinary importance due to the big losses it causes in livestock husbandry, ${ }^{9}$ the global scenario of fascioliasis has changed in the last three decades, ${ }^{10}$ with the description of numerous human-endemic areas and an increase of human

\footnotetext{
* Address correspondence to Santiago Mas-Coma, Departamento de Parasitologia, Facultad de Farmacia, Universidad de Valencia, Av. Vicent Andres Estelles s/n, Burjassot, Valencia 46100, Spain. E-mail: s.mas.coma@uv.es
}

reports in many countries. ${ }^{8}$ Human fascioliasis shows large transmission pattern complexity and epidemiological heterogeneity throughout, in great part linked to differences in human behavior, traditions, and diet underlying a marked diversity of human infection sources and incidence factors. ${ }^{11}$ New knowledge about involved foods, freshwater, and combinations of both carrying infective metacercariae allows us to understand the frequence of infection and reinfection by Fasciola spp. in rural areas. ${ }^{11,12}$

In human-endemic areas of developing countries, children appear to be the most affected, with prevalences and intensities showing a peak in the 9 - to 11 -year-old group. ${ }^{13}$ Information on rural child infection mainly relies on school surveys in which children are almost always detected in the chronic phase. Age-groups analyzed comprise from 5-yearold onward. The short knowledge about infection in preschool children aged 4 years or younger relies on sporadic reports.

Among the many human-endemic regions throughout, Southeast Asia has recently emerged. In Vietnam, an epidemic started in the mid-1990s. ${ }^{14}$ At present, many thousands of patients, mostly adult subjects, are yearly diagnosed in hospitals throughout the country. Both fasciolid species appear sympatrically, and hybrid forms have been described. ${ }^{15}$ This large public health problem in Vietnam may have expanded to neighboring Laos, ${ }^{16}$ and southern China. ${ }^{17}$

We here report five very young infected Vietnamese children, including early postnatal infection in two of them and an alarming picture leading to surgery in another. Focus is given to clinical features, useful diagnostic tools, molecular confirmation, treatment, and epidemiological aspects of interest. These cases may be interpreted as a worrying jump from an epidemic to an endemic situation. The long life span of Fasciola spp. in humans may give rise to chronic children if infection remains undiagnosed, as usual in rural areas. It should be considered that sequelae in this disease are known to increase with infection length. ${ }^{6,18}$ 
A comparison is made with similar cases reported worldwide. Reports in small children are analyzed, with special emphasis on the problems posed by diagnosis and treatment. Results highlight the need for physicians to consider potential infection by Fasciola spp. in not only very small children, even lactant ones, mainly when living in or visiting rural areas but also in urban children when suspicious foods and drinks made from sylvatic vegetables, fruits, tubercles, natural water, and/ or infection risky behavior are involved. ${ }^{11}$

\section{MATERIALS AND METHODS}

Ultrasonography (US) and serum biochemical parameters. An ultrasound-based imaging technique by means of a sonographic scanner was used because of its noninvasive technology appropriate for small children. Ultrasonography findings are nonspecific (diffuse liver echogenicity increase) during the invasive phase, but useful in the biliary period because of its ability to detect worm movements. Serum biochemical parameters useful in liver fluke-infected patients ${ }^{19}$ were measured within 2 hours after blood extraction by means of a standard enzymatic colorimetric method.

Coprological analysis. The Kato-Katz technique was applied to stool samples. Slides were microscopically examined at $\times 400$ within 1 hour of preparation to avoid egg overclarification. Egg counts (eggs per gram of feces [epg]) were used as indicator of liver fluke burden to assess whether special precautions should be taken in the treatment of heavily infected children, according to WHO instructions. ${ }^{6}$ Helminth egg measurements were obtained with a calibrated microscope by placing stool samples mixed with saline solution $(0.9 \%)$ onto a glass slide with a coverslip.

Serological test. A serological test is systematically applied to suspicious fascioliasis patients in Vietnam, where most patients do not shed Fasciola spp. eggs in stools, similarly as in other regions, for example, Europe. ${ }^{8}$ This ELISA to detect Fasciola spp. antibodies is based on a $27-\mathrm{kDa}$ component protein from excretory/secretory products of Vietnamese $F$. gigantica. This ELISA test showed a high sensitivity $(100 \%)$ and specificity $(97.67 \%) .{ }^{20}$ The cutoff applied was an optical density (OD) of 0.3 .

Molecular techniques. For DNA extraction, patients' eggs were isolated and embryonated up to inner miracidium development in 20 days under laboratory conditions. A 435-bp fragment of the mtDNA gene NADH dehydrogenase subunit I (nad1) could be obtained, using primers FND1F (forward) (5'TGGGGTCTGTTGCAGAGATTTGC3') and FND1R (reverse) (5'ATCCAATGGAGTACGGTTACA3') following methods previously described. ${ }^{15}$ Nucleotide and corresponding amino acid sequences were analyzed by alignments with nad1 sequences available in GenBank. Homologies were performed using the BLASTN program from the National Center for Biotechnology information website (http://www.ncbi.nlm. nih.gov/BLAST).

Literature review and quality assessment. A wide literature review to find reports of children aged 4 years or younger was performed by including databases, web entries, web platforms, multi-title packages, libraries, free collections, and personal e-mail requests when appropriate. The key criteria used to select the articles were the contents on 1) infection by $F$. hepatica or F. gigantica, and 2) children aged 4 years or younger. No restriction was applied to the period of time taken into consideration, that is, from the beginning of the oldest publication on human infection up to the present. Key words for literature searches included combinations of the following terms: fasciol, fluke, trematode, digenean, liver, hepatic, child, lactant, boy, girl, school, pre-school, diagnos, serol, coprol, stool, ultrasound, age, years, clinic, symptom, patho, eosinophil, anamnesis, epidemi, survey, famil, hospital, treatment, and fasciolicide. These terms were used in English, Spanish, French, German, Portuguese, Italian, and Vietnamese. Articles in other languages such as Polish, Turkish, or Russian were translated by using Internet translation tools. Old reviews and books were in need to be read in full because the appropriate information did not appear in titles, abstracts, summaries, or key words. Literature noted as references in published reports was useful. International library networks were used for the obtaining of publications not appearing in Internet or in cases in which only the title and/or the abstract could be found in Internet databases such as, for instance, Centre for Agriculture and Bioscience International, Pubmed, and others. Main criteria used to select the articles included verification that infection by Fasciola spp. was not misdiagnosed, and the information provided was sufficiently detailed. No restriction was applied to sources, that is, searches were not restricted to medical sources. Among gray literature analyzed, different types of reports, government documents, and working papers of agencies, universities, and research centers were screened by using Google open search through Internet. In countries presenting human fascioliasisendemic areas, a big amount of such literature was available in paper form, thanks to the network of scientists and centers collaborating in the Worldwide Initiative of WHO against Human Fascioliasis coordinated by the WHO Collaborating Centre on Fascioliasis and its Snail Vectors of Valencia, Spain.

Many reports were in publications not available in electronic databases. Special efforts were dedicated to obtain copies of the original publications or when impossible to at least get the possibility of direct or indirect consultation access.

In one case, fluke ascription to the genus Fasciola proved later to be a misdiagnosis. Four immature trematodes were found in the eye of a 5-month-old child in Germany 2 centuries ago. ${ }^{21}$ The causal agent was ascribed to $F$. hepatica several years after. ${ }^{22,23}$ This was a fatal case which generated a wide body of literature during the 19th and 20 th centuries. However, the last recent review concluded that it should not be considered a fascioliasis case because present evidences indicate these four ocular worms to have been mesocercariae of a trematode of the genus Alaria most probably after eventual transmammary transmission. ${ }^{6}$

A few surveys or case series referring to infection in the 0 - to 4-year age-group in several countries included no detailed data and are consequently not considered in the present review. However, these data and related references may be of interest and are summarized in the following.

In France, at the occasion of a fascioliasis epidemic occurred in an area close to the city of Nantes in the years 1965-1967, a report refers to 50 patients infected by F. hepatica and diagnosed at an hospital, including ages from 3 to 74 years. ${ }^{24}$ There is no other reference in the text as to even assess whether there was only a 3-year-old child or perhaps more than one aged 4 years or younger.

In Portugal, among a total of 561 subjects infected by $F$. hepatica in the northern part of the country close to Porto, a total of 21 children aged $0-6$ years were noted to be 
coprologically positive by egg detection, with a mean of 124 epg/child. ${ }^{25}$ No other information was furnished.

In Argentina, a 3-year-old child was noted to be infected by F. hepatica, supposedly in the area of Cordoba. Unfortunately, no additional information could be obtained despite the efforts made to have access to the unpublished $\mathrm{PhD}$ thesis where this case was reported (Siciliano C. Distomatosis hepática, perfil clínico. Tesis Doctoral, Universidad Nacional de Córdoba, Argentina. 1982; 1-118).

In Peru, in a retrospective study of 101 coprologically positive subjects in the northern province of Cajamarca, nine boy children and 19 girl children were noted to be infected in the 0 - to 9-year-old group, without any additional clarification. Anyway, reference to children in the school-age period suggests that all these children should probably have been 5 years or older. ${ }^{26}$ In a review of the clinical pictures of 2773 - to 86 -year-old patients diagnosed in an hospital in Lima during the 1970-2002 period, no detail is unfortunately noted about the smallest children infected. ${ }^{27}$ In a survey of schoolchildren in the Peruvian Altiplano, the 4- to 7-year-old group was considered among 61 positive cases examined, although no further details about the infection in 4-year-old children were mentioned. ${ }^{28}$

In Nigeria, a coprological survey of 6,430 children aged between 2 and 20 years was carried out in Benin City. Eggs of $F$. gigantica were noted to be found in the stools of two boy children and four girl children in the 2- to 5-year-old group of nursery pupils, without any additional information. It was noted, however, that false positives due to spurious infection by eggs in transit linked to local cattle infection were not disregarded. ${ }^{29}$

In Egypt, 134 subjects proven to have chronic fascioliasis after stool examination were enrolled in a study to evaluate the treatment with different triclabendazole regimes. A total of 87 subjects were females whose ages ranged from 2 to 60 years, but no further details about the smallest female(s) appear noted in the publication. ${ }^{30}$

In Iran, a survey of 452 blood samples was implemented after the human fascioliasis outbreak occurred in 1988 in Guilan Province, in the north of the country. The 0- to 9-yearold age-group was distinguished, although no further information was provided as to know whether children aged 4 years or younger were infected. ${ }^{31}$

Indirect access was obtained to consult an unpublished Medicine Speciality Thesis (Gomez CG. Fasciolosis hepática en humanos, hallazgos en ocho casos. Tesis de Especialidad en Anatomía Patológica, Facultad de Medicina, Universidad Nacional Autónoma de México, México. 1992; 1-40), in which two preschool child cases reported from Mexico were considered of interest and their data consequently included in the review.

Ethical statement. This study was approved by the Institutional Review Board for Ethics in Biomedical Research, Hanoi Medical University, Ministry of Health (Institutional Review Board No. 4018/HMUIRB). Patients originated from provinces of Vietnam and were diagnosed at the National Hospital of Pediatrics in Hanoi and the Hanoi Medical University. Informed consent from parents of the children was obtained in each case.

\section{RESULTS}

Infection in very young Vietnamese children. Results of the biochemical analyses of the five patients are shown in
Table 1. C-reactive protein (CRP) followed by creatinine (Cre), and from 3 years onward, also $\gamma$-glutamyl transferase (GGT) were the markers showing alterations.

Case 1. A 10-month-old girl, from the rural area of Phu Tho Province, presented with fever $\left(39^{\circ} \mathrm{C}\right)$, upper abdominal pain, plodding, weight loss $(0.5 \mathrm{~kg})$, and allergy. The parents referred to symptom onset 3 days before. Eosinophilia (20\%) and a visible lesion $(2.45 \times 2.07 \mathrm{~cm})$ in the right liver lobe by ultrasound (Figure 1A) were found. The serological analysis was positive (titer $1 / 6,400 ; O D=2.2$ ). Coprology showed an intensity of $48 \mathrm{epg}$, fluke eggs measuring $160 \times 90 \mu \mathrm{m}$ (Figure 2A). After treatment with $10 \mathrm{mg} / \mathrm{kg}$ single dose of triclabendazole, clinical symptoms and eggs in feces disappeared in 1 month, with evident gain in weight $(0.6 \mathrm{~kg}$ in 1 month). The parents had no symptoms and were serologically and coprologically negative. According to the parents, at home the baby was able to crawl to the yard and may have eaten (suck or chew) some freshwater plants collected from the field for their pig. Alternatively, the infection could have occurred by the consumption of freshwater plants added to the rice powdered soup given to the baby because of its 5 month age and the mother's insufficient lactating capacity.

Case 2. A 12-month-old boy, from the rural area of Bac Ninh Province, presented with fever $\left(39-40^{\circ} \mathrm{C}\right)$, upper abdominal pain, and weight loss $(0.7 \mathrm{~kg})$. Eosinophilia (25\%) and an evident damage $(3.50 \times 2.82 \mathrm{~cm})$ in the right liver lobe by ultrasound were found (Figure $1 \mathrm{~B}$ ). Positive serological test showed a titer of $1 / 3,200(O D=1.6)$. Intensity was $120 \mathrm{epg}$, eggs measuring $162 \times 92 \mu \mathrm{m}$ (Figure 2B). A similar successful recovery was obtained after a $10-\mathrm{mg} / \mathrm{kg}$ triclabendazole single dose treatment. Affected liver area damage progressively reduced up to total disappearance in 6 months. The parents were asymptomatic and negative serologically and coprologically.

Case 3. A 3-year-old girl, from the urban area of Dien Bien Province, presented with abdominal pain, chest pains, and fever $\left(38.5^{\circ} \mathrm{C}\right)$ as first symptoms. A weigh loss of $1.5 \mathrm{~kg} / \mathrm{month}$ had been observed. A $20 \%$ eosinophilia was found. A liver damage of $2.78 \times 2.16 \mathrm{~cm}$ in the right liver lobe was seen at ultrasound (Figure 1C). The serological positivity showed a titer of 1/3,200 (OD = 1.5). No eggs were detected in stool analyses, suggesting infection in the acute phase. After a month hospitalization, a fluke moving toward the pericardium and pericardial effusion were observed at US. The child fully recovered after a $20-\mathrm{mg} / \mathrm{kg}$ (1 tablet for $16 \mathrm{~kg}$ ) triclabendazole treatment. No other family member proved to be infected after serological and coprological examinations. The baby used to eat freshwater vegetables together with her parents.

Case 4. A 3-year-old boy, from the urban area of Nam Chai commune, Muong Khuong district, Lao Cai Province, presented with abdominal pain, cough, chest pains, and fever $\left(39^{\circ} \mathrm{C}\right)$ as first symptoms. Initially diagnosed as bronchitis, the treatment with antibiotic drugs proved to be useless. A tumor image appeared under right costal margin 20 days later. Effusion of lung membrane, pericardium, and abdomen was observed at US and X-ray (Figure 3). Eosinophilia was $53.4 \%$ in blood, $75 \%$ in lung effusion, and $80 \%$ in abdominal effusion. $\lg$ G was 25.38 (normal is 3.3-6.2), and IgE was 3,000 (normal is $0-230)$. Serological positivity showed a titer of $1 / 3,200$ (OD = 1.6). No eggs were found in stools, suggesting infection in the acute phase. The child fully recovered after a $20-\mathrm{mg} / \mathrm{kg}$ (1 tablet for $15 \mathrm{~kg}$ ) triclabendazole treatment. No other family 
TABLE 1

Results of biochemical parameters in serum obtained from two early postnatal and three preschool-age infected children in Vietnam, compared with same marker ranges for healthy children younger than 5 years in this country $\left(^{*}\right)$

\begin{tabular}{|c|c|c|c|c|c|c|c|}
\hline Biochemical markers & Units & $\begin{array}{l}\text { 10-month-old } \\
\text { girl (case 1) }\end{array}$ & $\begin{array}{l}\text { 12-month-old } \\
\text { boy (case 2) }\end{array}$ & $\begin{array}{l}\text { 3-year-old } \\
\text { girl (case 3) }\end{array}$ & $\begin{array}{c}\text { 3-year-old } \\
\text { boy (case 4) }\end{array}$ & $\begin{array}{c}\text { 4-year-old } \\
\text { boy (case 5) }\end{array}$ & $\begin{array}{l}\text { Healthy } \\
\text { children }^{*}\end{array}$ \\
\hline $\begin{array}{l}\text { Glutamic oxaloacetic } \\
\text { transaminase or aspartate } \\
\text { aminotransferase }\end{array}$ & U/L & 22 & 25 & 40 & 41 & 42 & $15-55$ \\
\hline $\begin{array}{l}\text { Glutamate-pyruvate } \\
\text { transaminase or alanine } \\
\text { aminotransferase }\end{array}$ & U/L & 31 & 28 & 39 & 40 & 41 & $5-40$ \\
\hline $\begin{array}{l}\text { Y-Glutamyl transferase } \\
\text { or Y-glutamyl } \\
\text { transpeptidase }\end{array}$ & U/L & 28 & 34 & 41 & 39 & 40 & $5-32$ \\
\hline Total bilirubin & $\mu \mathrm{mol} / \mathrm{L}$ & 9.5 & 11 & 5.5 & 6.6 & 15 & $2-20$ \\
\hline Calcium & $\mathrm{mmol} / \mathrm{L}$ & 2.5 & 2.2 & 2.0 & 2.1 & 1.8 & $2.2-2.7$ \\
\hline Chloride & $\mathrm{mmol} / \mathrm{L}$ & 100 & 103 & 99 & 98 & 101 & $98-106$ \\
\hline Creatinine & $\mu \mathrm{mol} / \mathrm{L}$ & 60.5 & 66.5 & 76.5 & 63 & 90 & $27-62$ \\
\hline Urea & $\mathrm{mmol} / \mathrm{L}$ & 5.6 & 4.7 & 4.6 & 5.3 & 3.5 & $2.5-6.4$ \\
\hline Albumin & $\mathrm{g} / \mathrm{L}$ & 40 & 43 & 46 & 39 & 35 & $37-51$ \\
\hline Total protein & g/L & 72 & 62 & 77 & 66 & 65 & $57-80$ \\
\hline Glucose & $\mathrm{mmol} / \mathrm{L}$ & 5.2 & 4.8 & 4.1 & 5.1 & 4.3 & $3.3-5.5$ \\
\hline Amylase & U/L & 160 & 155 & 100 & 120 & 150 & $\leq 220$ \\
\hline Total cholesterol & $\mathrm{mmol} / \mathrm{L}$ & 4.5 & 4.0 & 3.9 & 4.1 & 4.6 & $<4.42$ \\
\hline Triglycerides & $\mathrm{mmol} / \mathrm{L}$ & 1.5 & 0.9 & 1.7 & 1.2 & 2.1 & $<1.65$ \\
\hline C-reactive protein & mg/L & 8 & 10 & 12 & 33.95 & 9 & $<6.0$ \\
\hline
\end{tabular}

Altered values marked in bold.

members were infected according to serology and coprology. The baby used to eat freshwater vegetables.

Case 5. A 4-year-old boy, from the urban area of Loc Vuong community in Nam Dinh Province, suffered fever of $39^{\circ} \mathrm{C}$ followed by abdominal pain appearing after 2 weeks and weight loss of around $2 \mathrm{~kg} /$ month. A $3.23 \times 2.35-\mathrm{cm}$ lesion was observed in the right liver lobe by ultrasound (Figure 1D). A $17 \%$ eosinophilia was found. Two weeks later, a fluke moving
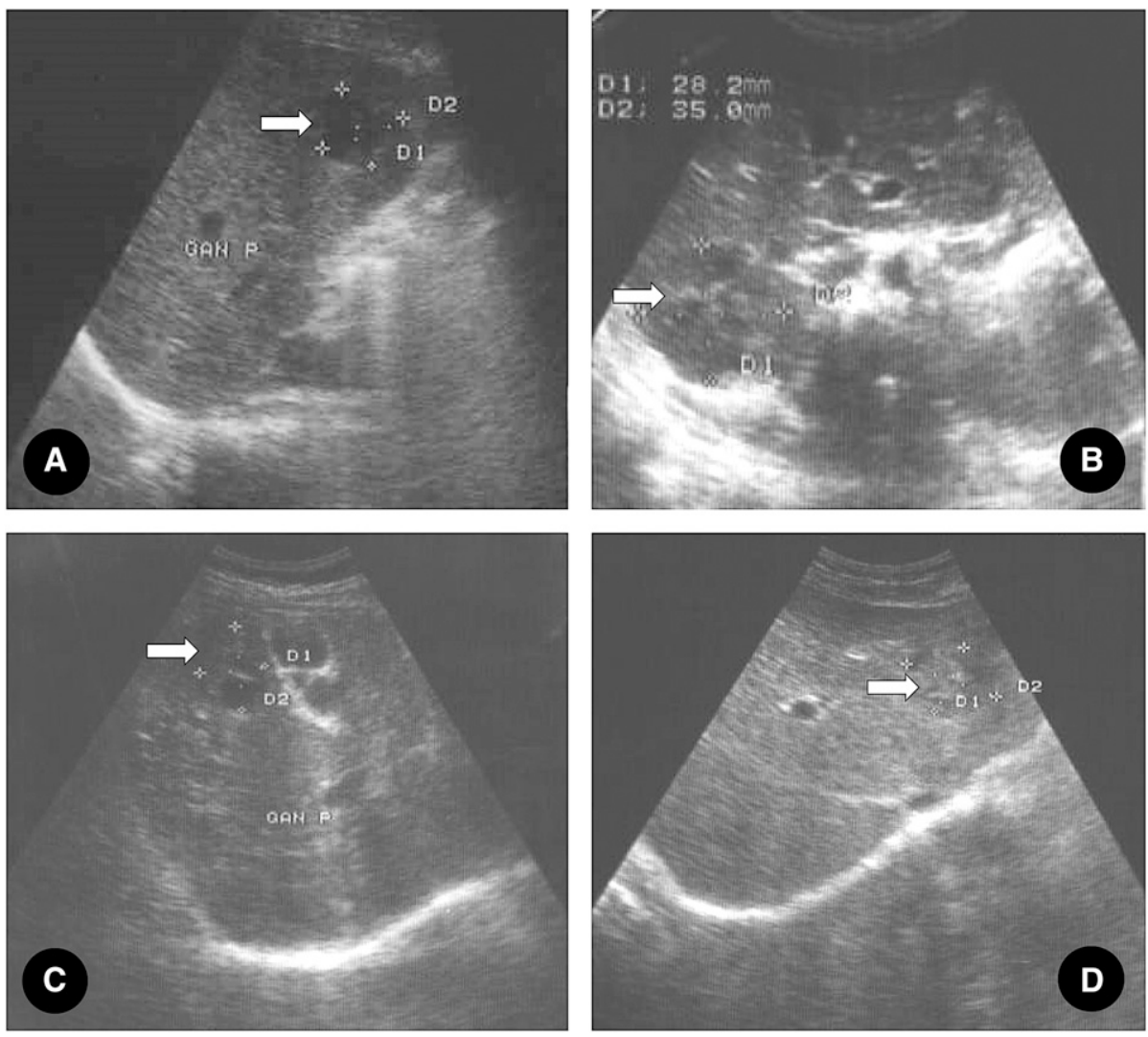

FIGURE 1. Ultrasonography images showing lesions in the right liver lobe (arrows) of four Vietnamese preschool children: (A) lesion of $2.45 \times 2.07$ $\mathrm{cm}$ in a 10-month-old girl (case 1); (B) damage sized $3.50 \times 2.82 \mathrm{~cm}$ in a 12-month-old boy (case 2); (C) damage of $2.78 \times 2.16 \mathrm{~cm}$ in a 3 -year-old girl (case 3); (D) lesion of $3.23 \times 2.35 \mathrm{~cm}$ in a 4-year-old boy (case 5). 


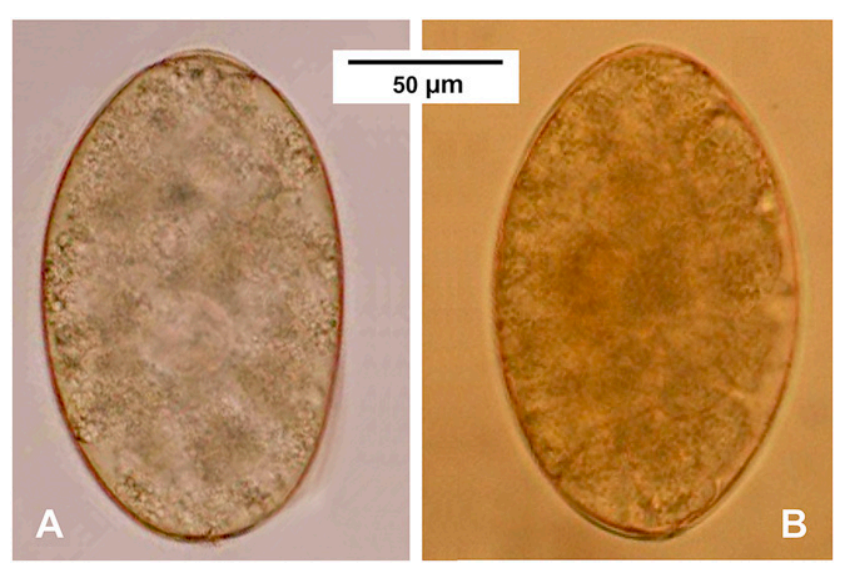

FIGURE 2. Eggs of Fasciola gigantica fecally shed by earliest infected children ever reported: (A) from girl baby presumably infected at 5 months (case 1); (B) from male baby presumably infected at 7 months (case 2). Note the appearance of normal viable fasciolid eggs, with anterior operculum and typical roughened or irregular area at the abopercular end. This figure appears in color at www.ajtmh.org.

from the liver to the large intestine was seen at ultrasound. Subsequently, peritonitis appeared accompanied by increased fever and abdominal pain. Serology showed positivity (titer of $1 / 6,400 ; O D=2.1$ ), but coprology was negative. Additional symptoms included increased fever, swollen abdomen, nausea and vomiting, diarrhea, additional weight loss, and fluid filled abdominal cavity (ascites). This alarming picture led to surgery, in which perforation of the large intestine was found, and a 34-mm-long fluke in the abdominal cavity was collected (Figure 4A and B). Treatment with $20 \mathrm{mg} / \mathrm{kg}$ (1 tablet for $18 \mathrm{~kg}$ ) triclabendazole led to total healing. Father and mother showed no infection at serology and coprology. Parents referred to the usual consumption of freshwater vegetables by their son.

Molecular confirmation of causal agent. Comparative nucleotide alignments with nad1 sequences available in the

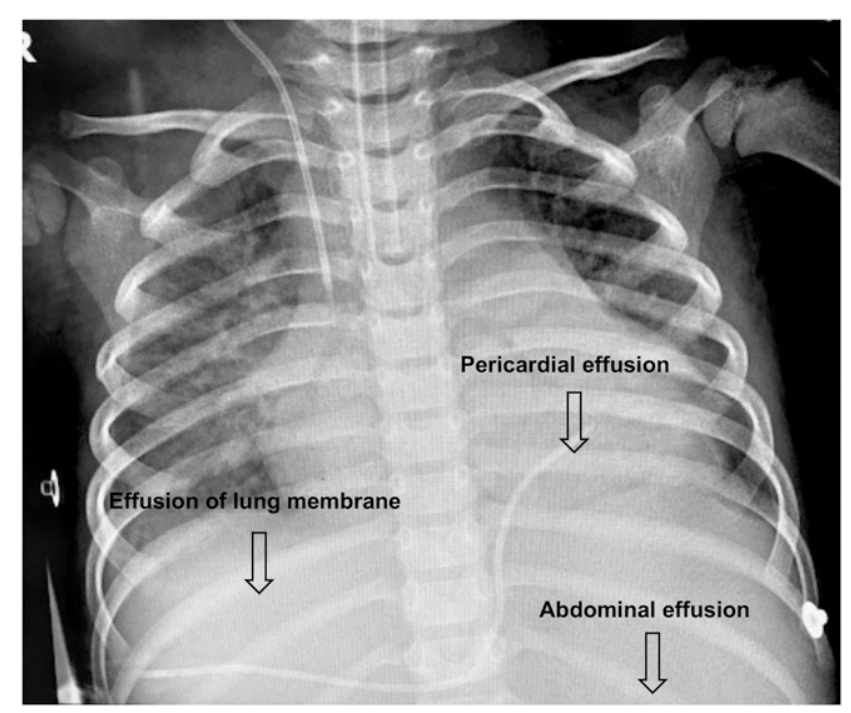

FIGURE 3. Effusion of the lung membrane, pericardium, and abdomen observed at X-ray caused by Fasciola sp. infection in a 3-year-old boy (case 4).
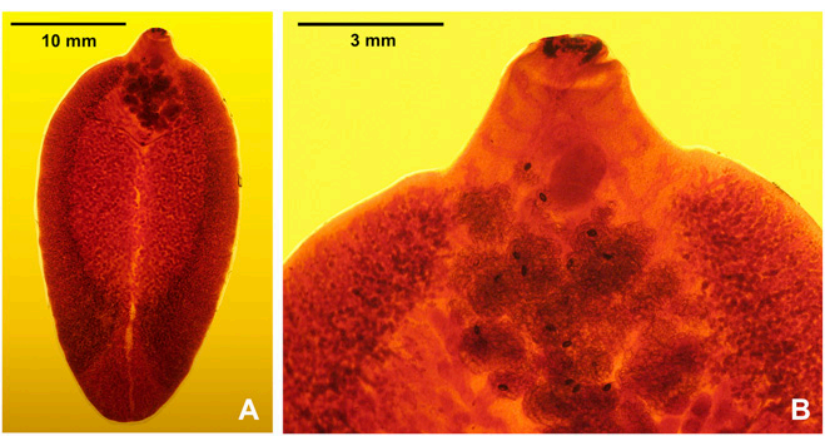

FIGURE 4. Largest ectopic gravid fasciolid specimen ever reported, surgically collected from the abdominal cavity of a 4-year-old boy, causing peritonitis after intestinal wall perforation (case 5): (A) ventral view of complete 34-mm-long Fasciola gigantica-like adult showing anterior shoulders and nonparallel lateral walls; (B) anterior part showing long coiled uterus full of eggs. This figure appears in color at www.ajtmh.org.

GenBank database showed high nucleotide (98-99\%) and amino acid (96-99\%) similarity to nad1 sequences of F. gigantica from Korea, Japan, and Indonesia, but a lower rate (90\% and $92 \%$ ) than those of $F$. hepatica from Australia and the Americas (Table 2).

Fascioliasis reports in worldwide preschool children. In human-endemic areas and among human cases in animalendemic areas, human infection reports become numerous from the age of 5 years, that is, from the beginning of school years. This has traditionally been linked to the risky daily walking way from home to the school in rural areas because of the opportunities for infection when children put sylvatic vegetables into the mouth or drink natural water.

The review performed has been restricted to preschool children aged 4 years or younger (Tables 3 and 4 ). A total of 38 past cases were found, including $3,7,12$, and 16 cases of 1,2, 3 , and 4 years, respectively. They comprised 22 boy children, eight girl children, and eight with unspecified gender. There is an evident faster increase of infection in males than in females from 2 years onward (Figure 5).

Reports were from all continents, except Oceania, including 10 cases in Europe (three in Austria and one in each Croatia, France, Italy, Poland, Spain, Switzerland, and the United Kingdom), eight in Africa (Egypt 6, Algeria 1, and Ethiopia 1), five in Asia (China 1, India 1, Iran 2, and Turkey 1), and 15 in the Americas (Argentina 1, Bolivia 1, Cuba 1, Guatemala 1, Mexico 7, and Peru 4).

The oldest report dates from 1856 in the United Kingdom and the most recent from 2016 in Peru, including many different types of reports. This long interval explains the use of many anti-fasciolid drugs according to the different periods: emetine, dehydroemetine, entobex, bithionol, praziquantel, triclabendazole, and nitazoxanide.

In the reports in which a specific diagnosis was achieved, the causal agent was always noted to be F. hepatica. Among the 38 globally reported cases, only in four from Egypt and two from Iran was the worm species not defined and cannot be established because of the geographical distribution overlap of the two fasciolid species in these two countries. There were 11 cases diagnosed in the acute phase, 24 in the chronic phase, and three ectopic cases. Only in five cases was intensity assessed by egg counts, always referring to a low 
TABLE 2

Comparison of mtDNA nad1 sequences ( 435 nucleotides and 145 amino acids) from eggs shed by Vietnamese small children with Fasciola gigantica from Japan, Korea, and Indochina, and Fasciola hepatica from Australia and the Americas

\begin{tabular}{|c|c|c|c|c|}
\hline Comparisons & Number of different nucleotides & Homology rate of nucleotides & Number of different amino acids & Homology rate of amino acids \\
\hline FgCase1 vs. FgCase2 & 0 & $100 \%$ & 0 & $100 \%$ \\
\hline FgCases 1 and 2 vs. FgJp & 2 & $99.5 \%$ & 2 & $98.5 \%$ \\
\hline FgCases 1 and 2 vs. FgKor & 2 & $99.5 \%$ & 2 & $98.5 \%$ \\
\hline FgCases 1 and 2 vs. Fglndo & 4 & $99.1 \%$ & 3 & $97.8 \%$ \\
\hline FgCases 1 and 2 vs. FhAus & 39 & $90.4 \%$ & 11 & $91.8 \%$ \\
\hline FgCases 1 and 2 vs. FhUS & 39 & $90.4 \%$ & 11 & $91.8 \%$ \\
\hline
\end{tabular}

burden between 5 and 48 epg, except 1,197 epg in a 4-yearold boy.

The only two cases detected in family outbreaks are surprising. The majority were detected in hospitals (28 cases) or surveys (six cases), with one case during a drug evaluation trial. Symptom onset, when noted, was of a maximum of 4 months. Eosinophilia appears as a general feature.

\section{DISCUSSION}

Parasitological analysis. The cases 1 and 2 are the youngest fascioliasis patients ever diagnosed. When considering the five infected preschool children, Vietnam becomes the third after Mexico and Egypt in the country list according to the number of such reports.

These Vietnamese preschool children are the first reported to be infected by F. gigantica. Egg size in cases 1 and 2 corresponds to the overlap range in areas where both fasciolid species are present: F. hepatica: 106.5-171.5/63.9-95.4 $\mu \mathrm{m}$; F. gigantica: 150.9-182.2/85.1-106.2 $\mu \mathrm{m}^{8}{ }^{8}$ The $34.00-\mathrm{mm}-$ long mature fluke recovered from case five indicates infection by $F$. gigantica because of its length: $F$. gigantica up to $52.3 \mathrm{~mm}$; F. hepatica up to only $29.0 \mathrm{~mm}$. ${ }^{63}$ The mtDNA nad1 sequences from eggs in cases 1 and 2 demonstrate that a $F$. gigantica form was involved. It may be concluded that the infections were caused by F. gigantica-like worms, ${ }^{5}$ which agrees with previous molecular analyses of fasciolids in Vietnam. ${ }^{15}$ Egg absence did not allow for a specific diagnosis in cases 3 and 4.

The prepatent period in $F$. gigantica is at least $1-2$ weeks longer than in $F$. hepatica. ${ }^{19}$ Consequently, the chronic cases 1 and 2 should have been infected at least when they were aged 5-6 months and 7-8 months, respectively. This means a very early postnatal infection during the lactating period. Three other infections by Fasciola spp. in lactating children were reported from Mexico, ${ }^{32}$ Egypt, ${ }^{33}$ and Argentina. ${ }^{34}$

Pathogenicity and epidemiological aspects. Fasciola gigantica is more pathogenic than $F$. hepatica because of its larger size. ${ }^{19}$ Worth mentioning is that cases 1 and 2 were not diagnosed during the acute phase, in which symptoms are more evident than in the chronic phase. ${ }^{6}$ Indeed, in human hyperendemic rural areas of developing countries, children are almost always detected in the chronic phase. ${ }^{13}$ Whereas egg absence indicates cases 3 and 4 to be in the acute phase, egg presence in the surgically obtained fluke indicates case 5 to be in the chronic phase.

Such early infections suggest that children in rural areas of developing countries may reach chronicity very early in their lives, a situation of concern for their development considering complications such as anemia, lithiasis or cirrhosis, and sequelae, which are known consequences of the advanced chronicity, ${ }^{64-66}$ and to be worse in long-term infections because of delayed diagnosis and treatment. ${ }^{67}$ Peritonitis diagnosed in the chronic case 5 is a complication already emphasized in children. ${ }^{68,69}$ Ectopic case five demonstrates that adult flukes have the capacity to abandon the liver, reach the intestine, and restart migration crossing the intestinal wall.

Other worth mentioning severe complications reported in these small children were liver abscess, ${ }^{46}$ multiple hepatic cysts, ${ }^{34}$ and neurological affection, ${ }^{49}$ the latter even leading to death. ${ }^{55}$

C-reactive protein followed by Cre and GGT appears as the most useful serum biomarkers. As a highly sensitive marker for liver inflammation associated with infection, CRP may also be useful to assess treatment efficacy because it returns quickly to normal values in response to therapy. C-reactive protein and GGT, besides aspartate aminotransferase and alanine aminotransferase, were also altered at the acute phase in a 3year-old boy, ${ }^{47}$ as usual in fascioliasis patients. ${ }^{19}$

The higher frequence of pseudo-septicemic forms in 5- to 16-year-old children than in adult subjects was highlighted in Europe, ${ }^{70}$ including three 4 -year-old children in Austria, ${ }^{49}$ Italy, ${ }^{50}$ and Switzerland. ${ }^{51}$ Liver fluke infection induces suppression of immune responses against concurrent pathogenic infections, not only bacteria but also protozoans and other helminths, in both acute ${ }^{71}$ and chronic phases. ${ }^{72}$ These coinfections are known to underlie morbidity and mortality. Suffering from such immunosuppression effects at such early ages becomes an evident problem.

The infection source in such early infected children is a question mark, as the first deciduous teeth appear from months 6 to 9 and the last ones from months 20 to 24. Contaminated water, beverages, juices, and soups made from sylvatic vegetables, fruits, and even tubercles, as well as plant sucking, may underlie these infections. ${ }^{11}$ Watercress and lettuce leaves were noted to be involved in some cases. ${ }^{32,33}$

The absence of infection by Fasciola spp. in the parents of the Vietnamese children is not easily understandable because parents referred to their children sharing the same vegetables with them. Different immunological capacities may be involved in infections by a very low number of metacercariae. However, only two infected preschool children were reported in family outbreaks. ${ }^{53,54}$ The isolated preschool child infections suggest that many such infections may remain overlooked because they are undiagnosed or misdiagnosed in rural areas.

The clear dominance of males over females is surprising, as significantly higher prevalences and/or intensities in 
DE AND OTHERS

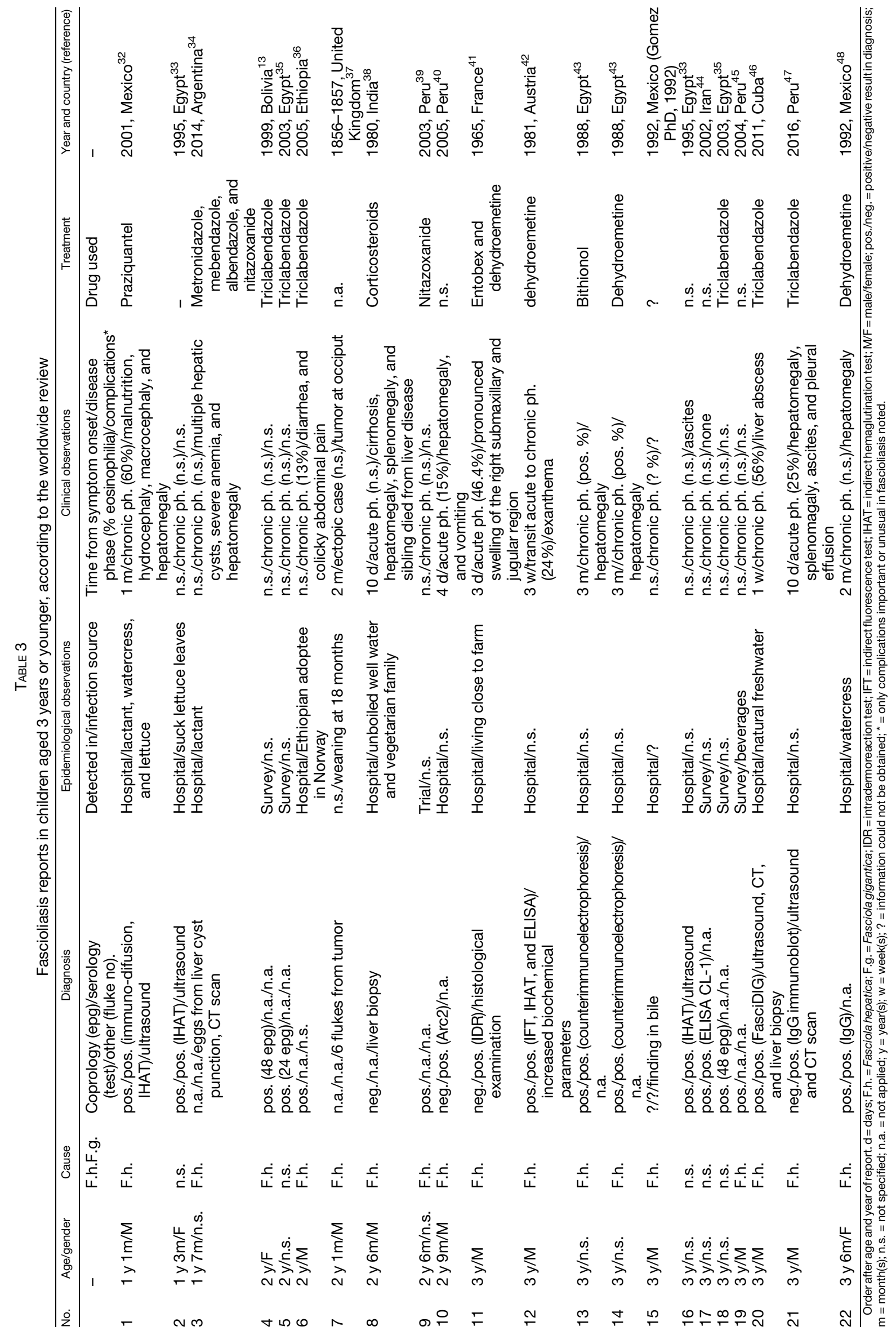




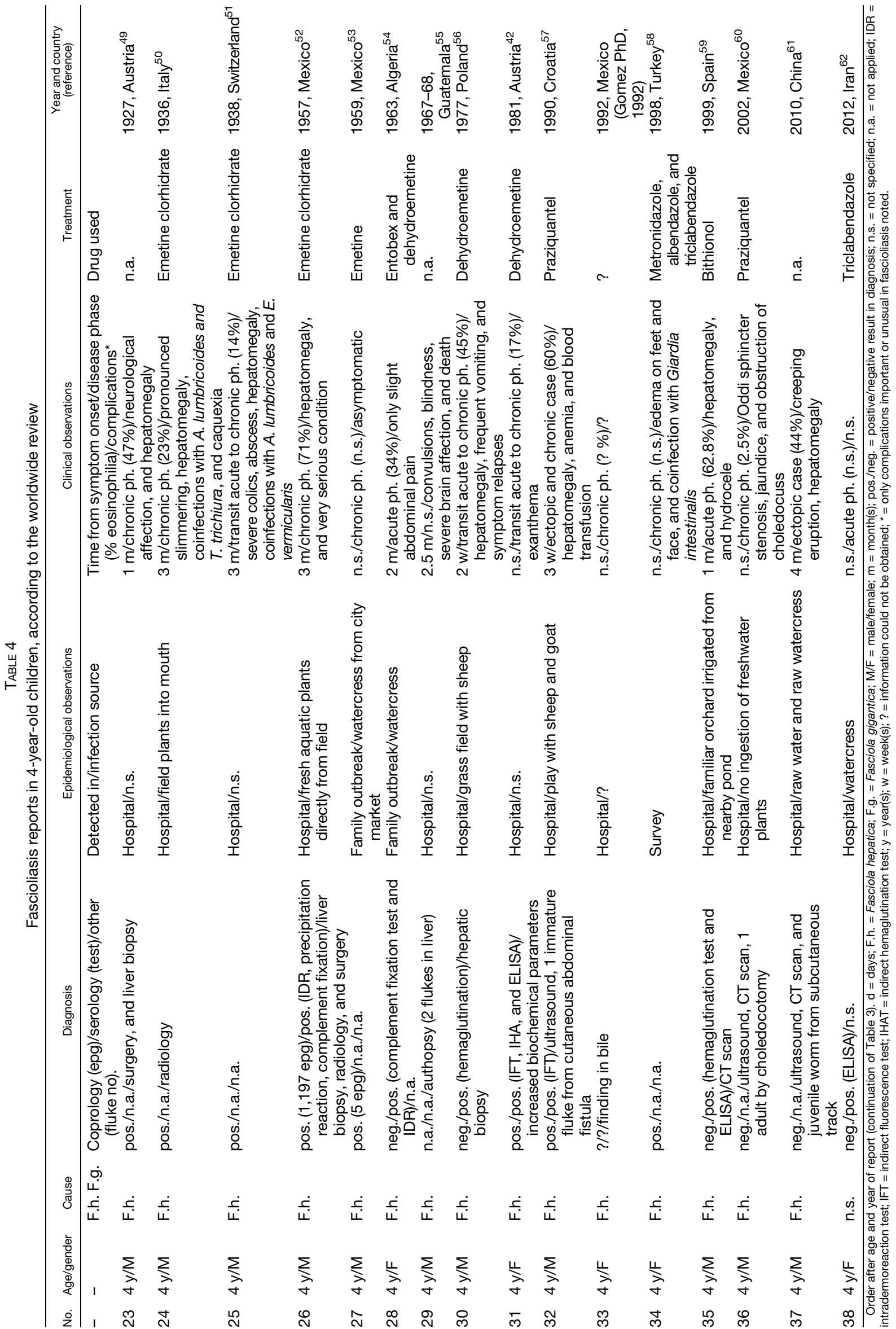




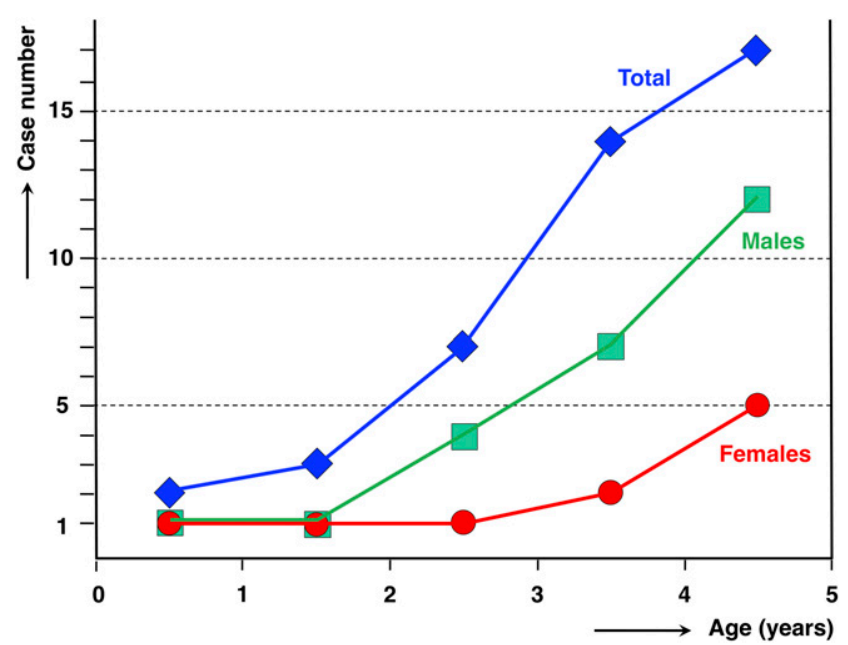

FIGURE 5. Relationship of case numbers with age, according to the worldwide data reviewed: progressive increase of total preschool children (including reports with unspecified gender) and faster increase of frequency in males than in females from the age of 2 years. Five Vietnamese cases here reported included. This figure appears in color at www.ajtmh.org.

females have repeatedly been highlighted in developing countries, ${ }^{5,8,13}$ and also in schoolchildren in western Europe. ${ }^{70}$ Differentiation appearing from the age of 2 years may perhaps be linked to a higher activity and more precocious curiosity of males in sucking or putting things into the mouth.

The very low epg amounts in cases 1 and 2 agree with infections in Bolivia ${ }^{13}$ and Egypt. ${ }^{35}$ This suggests that high burdens in schoolchildren of hyperendemic areas may in some cases be the consequence of fluke accumulation by long-term reinfections started very early in life. ${ }^{73}$

Although several reports on infected small children are from developed countries where human infection by Fasciola spp. continues to be diagnosed, ${ }^{74}$ countries where more infected preschool children were reported agree with those known to present human-endemic areas, for example, Mexico, ${ }^{75}$ Egypt where the highest human prevalence in Africa has been reported, ${ }^{76}$ and Peru. ${ }^{45,77}$ Bolivia should be highlighted because of only one such case, ${ }^{13}$ despite presenting the highest human hyperendemic area known, $5,8,11$ suggesting a possible overlook of preschool infections. In Peru, there is indeed reference to unpublished observations on fascioliasis in children from an age of 2 years. ${ }^{40}$ Fascioliasis is a neglected non-reportable infection, ${ }^{74}$ which explains why many such child cases are never published or, when reported, usually with very restricted diffusion. ${ }^{33,34,37,54,55}$

Diagnosis and treatment. A serological test and a coprological analysis are recommended for the detection of infection during the acute and the chronic phases in so small children. Typical fascioliasis symptoms may be overlooked, mainly when the infection is by only one or two flukes, which appears to be the most usual situation in these children. A high sensitivity coproantigen detection test may also be very useful in the chronic phase of these extreme low-burden infections, ${ }^{78}$ even before the beginning of egg appearance in stools. ${ }^{19}$ Right upper quadrant and abdominal pain, fever, weight loss, and eosinophilia, accompanied by alteration of the biochemical markers (at least liver function tests, CRP, and
Cre), ${ }^{19}$ and liver observation through ultrasound (or computerized tomography [CT] scan if available), may help. Anamnesis including parent's information about suspicious infection sources may be crucial in guiding to a faster and correct diagnosis. ${ }^{11}$ The modern trend for "natural feeding habits" by prioritizing the consumption of non-treated, fresh, raw/green fruits, and vegetables, when not also natural water, becomes risky for small children if used for beverages, juices, and soups. ${ }^{11}$

Lack of symptomatic cure, disease relapses, insufficient efficacy despite long treatment courses, and need for retreatments after egg reappearance in stools have been highlighted in preschool children treated with different drugs. ${ }^{42,43,56}$ Only triclabendazole appears to avoid such problems, undoubtedly because of its unique action on both intra-tissularly migrating juveniles and fluke adults. ${ }^{79}$ The present work fills the information gap related to the usefulness and applicability of triclabendazole for the treatment of early postnatal infections and preschool-age child infections. In the smallest Vietnamese children, a $10-\mathrm{mg} / \mathrm{kg}$ single dose post-prandially administered was sufficient for the disappearance of clinical symptoms and eggs in feces in 1 month, and to obtain a subsequent evident gain in weight. Reappearance of eggs in stools 2 months after the first $10 \mathrm{mg} / \mathrm{kg}$ dose was, however, reported in a 4-year-old girl in Turkey. ${ }^{58}$ This girl responded well to a second $10 \mathrm{mg} / \mathrm{kg}$ dose, eggs disappeared, and she remained free of complaints during a whole year follow-up. The aforementioned short 2-month period suggests triclabendazole to have not been initially efficient against a migratory fluke originated in a reinfection. The drug was well tolerated with the exception of mild temporary right upper abdominal pain. ${ }^{58}$ Similarly, no serious side effects were reported in other small children treated with triclabendazole, for example, a 2-year-old Ethiopian boy in Norway, ${ }^{36}$ a 2-yearold girl in Bolivia, ${ }^{13}$ 2- and 3-year-old children in Egypt, ${ }^{35}$ a 3year-old boy in Cuba, ${ }^{46}$ and a 3 -year-old boy in Peru. ${ }^{47}$ In the three 3- and 4-year-old Vietnamese children, a $20-\mathrm{mg} / \mathrm{kg}$ dose ( 1 tablet for 16,15 , and $18 \mathrm{~kg}$, respectively) was also well tolerated, no side effects were observed, and led to total healing.

In addition, it should here be remembered that, when in the chronic phase, egg counts (epg) should be assessed by means of a quantitative coprological diagnostic test, such as the Kato-Katz. ${ }^{8}$ Children with an intensity of infection of $\geq 400$ epg should be hospitalized before receiving treatment. This is justified by the consideration that individuals infected with a large number of worms are more likely to develop both systemic and mechanical adverse events (e.g., hepatic colic) following treatment and might, therefore, require specialist medical attention and care. ${ }^{80} \mathrm{~A}$ lower threshold of $\geq 300 \mathrm{epg}$ was requested in Bolivia where intensities in children are known to reach very high levels. ${ }^{13}$ For very small children aged 4 years or younger, this threshold may be even reduced as precautionary measure. The finding of a 1,197 epg in a 4-yearold Mexican boy presenting with a very serious condition is worrying. ${ }^{52}$ It should also be considered that a coproantigen test is not useful for this purpose because concentration of coproantigens in feces does not correlate with epg. ${ }^{81}$

One unavoidably wonders about how many such early infections may remain undiagnosed or misdiagnosed. Family doctors and pediatricians should consider them in areas where fascioliasis is a public health problem, and also in livestock hyperendemic rural areas. 
Received February 23, 2020. Accepted for publication May 20, 2020.

Published online July 6, 2020.

Financial support: This research was funded by Vietnam National Foundation for Science and Technology Development (NAFOSTED) under grant number 108.05-2017.301. Spanish collaboration funded by project number SAF2010-20805 of the Ministry of Economy and Competitiveness (MINECO), Madrid, Spain; by Health Research project number PI16/00520, Subprograma Estatal de Generación de Conocimiento de la Acción Estratégica en Salud (AES), Plan Estatal de Investigación Científica y Técnica y de Innovación y Fondos FEDER, ISCIII-MINECO/FEDER, Madrid, Spain; by project number 2017/ ACDE/001583 de Innovación para el Desarrollo of the Agencia Española de Cooperación Internacional para el Desarrollo (AECID), Ministry of Foreign Affairs and Cooperation, Madrid, Spain; and by the Red de Investigación de Centros de Enfermedades Tropicales-RICET (Project number RD16/0027/0023 of the PN de I+D+l, ISCIII-Subdirección General de Redes y Centros de Investigación Cooperativa RETICS), Ministry of Health and Consumption, Madrid.

Disclosure: Studies of this article have been performed within the framework of the Worldwide Initiative of WHO against Human Fascioliasis (WHO Headquarters, Geneva, Switzerland). The support by the Department of Control of Neglected Tropical Diseases, World Health Organization, WHO/OMS, Geneva, Switzerland, is greatly acknowledged for their help in facilitating the international collaboration necessary for the research activities developed.

Authors' addresses: Nguyen Van De, Department of Parasitology, Hanoi Medical University, Hanoi, Vietnam, E-mail: ngvdeyhn@ gmail.com. Thanh Hoa Le, Department of Immunology, Institute of Biotechnology, Vietnam Academy of Science and Technology, Hanoi, Vietnam, E-mail: imibtvn@gmail.com. Veronica H. Agramunt and Santiago Mas-Coma, Departamento de Parasitología, Facultad de Farmacia, Universidad de Valencia, Valencia, Spain, E-mails: veronica.hernandez@uv.es and s.mas.coma@uv.es.

\section{REFERENCES}

1. World Health Organization, 2013. Sustaining the Drive to Overcome the Global Impact of Neglected Tropical Diseases. Geneva, Switzerland: WHO, 1-138.

2. Boissier J, Mone H, Mitta G, Bargues MD, Molyneux D, MasComa S, 2015. Schistosomiasis reaches Europe. Lancet Infect Dis 15: 757-758.

3. Afshan K, Fortes-Lima CA, Artigas P, Valero MA, Qayyum M, MasComa S, 2014. Impact of climate change and man-made irrigation systems on the transmission risk, long-term trend and seasonality of human and animal fascioliasis in Pakistan. Geospatial Health 8: 317-334.

4. Mas-Coma S, Valero MA, Bargues MD, 2009. Climate change effects on trematodiases, with emphasis on zoonotic fascioliasis and schistosomiasis. Vet Parasitol 163: 264-280.

5. Mas-Coma S, Valero MA, Bargues MD, 2009. Fasciola, lymnaeids and human fascioliasis, with a global overview on disease transmission, epidemiology, evolutionary genetics, molecular epidemiology and control. Adv Parasitol 69: 41-146.

6. Mas-Coma S, Agramunt VH, Valero MA, 2014. Neurological and ocular fascioliasis in humans. Adv Parasitol 84: 27-149.

7. Bargues MD, Artigas P, Khoubbane M, Flores R, Glöer P, RojasGarcía R, Ashrafi K, Falkner G, Mas-Coma S, 2011. Lymnaea schirazensis, an overlooked snail distorting fascioliasis data: genotype, phenotype, ecology, worldwide spread, susceptibility, applicability. PLoS One 6: e24567.

8. Mas-Coma S, Bargues MD, Valero MA, 2014. Diagnosis of human fascioliasis by stool and blood techniques: update for the present global scenario. Parasitology 141: 1918-1946.

9. Mehmood $\mathrm{K}$ et al., 2017. A review on epidemiology, global prevalence and economical losses of fasciolosis in ruminants. Microb Pathog 109: 253-262.

10. Chen MG, Mott KE, 1990. Progress in assessment of morbidity due to Fasciola hepatica infection: a review of recent literature. Trop Dis Bull 87: R1-R38.

11. Mas-Coma S, Bargues MD, Valero MA, 2018. Human fascioliasis infection sources, their diversity, incidence factors, analytical methods and prevention measures. Parasitology 145: 1665-1699.

12. Ashrafi K, Valero MA, Massoud J, Sobhani AR, SolaymaniMohammadi S, Conde P, Khoubbane M, Bargues MD, MasComa S, 2006. Plant-borne human contamination by fascioliasis. Am J Trop Med Hyg 75: 295-302.

13. Esteban JG, Flores A, Angles R, Mas-Coma S, 1999. High endemicity of human fascioliasis between Lake Titicaca and La Paz valley, Bolivia. Trans $R$ Soc Trop Med Hyg 93: 151-156.

14. De NV, 2012. Situation of fascioliasis in Vietnam [article in Vietnamese]. J Malariol Parasitol Control 2: 17-20.

15. Le TH, De NV, Agatsuma T, Nguyen TGT, Nguyen QD, McManus DP, Blair D, 2008. Human fascioliasis and the presence of hybrid/introgressed forms of Fasciola hepatica and Fasciola gigantica in Vietnam. Int $J$ Parasitol 38: 725-730.

16. Quang TD, Duong TH, Richard-Lenoble D, Odermatt $P$, Khammanivong K, 2008. Émergence chez l'homme de fasciolose à Fasciola gigantica et de distomatose intestinale à Fasciolopsis buski au Laos. Cahiers Santé 18: 119-124.

17. Chen JX et al., 2013. An outbreak of human fascioliasis gigantica in southwest China. PLoS One 8: e71520.

18. Rondelaud D, Dreyfuss G, Vignoles P, 2006. Clinical and biological abnormalities in patients after fasciolosis treatment. Symptômes cliniques et anomalies biologiques chez des patients après le traitement d'une fasciolose. Méd Malad Infect 36: 466-468.

19. Valero MA et al., 2016. Higher physiopathogenicity by Fasciola gigantica than by the genetically close $F$. hepatica: experimental long-term follow-up of biochemical markers. Trans $R$ Soc Trop Med Hyg 110: 55-66.

20. Nguyen TGT, Le TH, De NV, Doan TT, Dao THT, Vercruysse J, Dorny $\mathrm{P}, 2010$. Assessment of a $27-\mathrm{kDa}$ antigen in enzymelinked immunosorbent assay for the diagnosis of fasciolosis in Vietnamese patients. Trop Med Int Health 15: 462-467.

21. Gescheidt A, Von Ammon FA, 1833. Die Entozoa des Auges. Zeitschr Ophthalmol 3: 70-76.

22. Leuckart R, 1863. Die Menschlichen Parasiten und die von ihnen Herrührenden Krankheiten. Band 1. Leipzig und Heidelberg: C.F. Winter'sche Verlagshandlung, 1-766.

23. Castellani A, Chalmers AJ, 1919. Manual of Tropical Medicine, 3rd edition. London, United Kingdom: Ballière, Tindall and Cox, 1-2436.

24. Giraudet J, 1968. Réflexions sur une épidémie de distomatose hépatique humaine. Etude sur 50 observations en milieu hospitalier. Presse Med 76: 189-192.

25. Sampaio-Silva ML, 1990. Annex. Summary of a report on Fasciola hepatica infection in northern Portugal from the Instituto Nacional de Saude, Porto, Portugal. Chen MG, Mott KE, eds. Progress in Assessment of Morbidity due to Fasciola hepatica Infection: $A$ Review of Recent Literature. Trop Dis Bull 87: R1-R38.

26. Alban Olaya M, Jave Ortiz J, Quispe Lazo T, 2002. Fascioliasis en Cajamarca. Rev Gastroenterol Peru 22: 1-8.

27. Blancas G, Terashima A, Maguiña C, Lujan L, Alvarez H, Casanova RT, 2004. Fasciolosis humana y compromiso gastrointestinal: estudio de 277 pacientes en el Hospital Nacional Cayetano Heredia, 1970-2002. Rev Gastroenterol Peru 24: 143-157.

28. Marcos L, Maco V, Samalvides F, Terashima A, Espinoza JR, Gotuzzo E, 2006. Risk factors for Fasciola hepatica infection in children: a case-control study. Trans $R$ Soc Trop Med Hyg 100: 158-166.

29. Okaka CE, Awharitoma AO, Okonji JN, 2000. Gastrointestinal parasites of school children in Benin city, Nigeria. Iran J Publ Health 29: 1-12.

30. El-Morshedy H, Farghaly A, Sharaf S, Abou-Basha L, Barakat R, 1999. Triclabendazole in the treatment of human fascioliasis: a community-based study. Rev Santé Mediterranée Orient 5: 888-894.

31. Assmar M, Milaninia A, Amirkhani A, Yadegari D, Forghan-Parast K, Nahravanian H, Piazak N, Esmayli A, Hovanesian A, Valadkhani Z, 1991. Seroepidemiological investigation of fascioliasis in northern Iran. Med J Islam Repub Iran 5: 23-27.

32. Sanchez Vega JT, Tay Zavala J, Salinas Velasco R, Ruiz Sanchez D, Ordoñez Martinez JJ, Rodriguez Cobarrubias JA, 2001. Fascioliosis. Presentación de un caso y revisión acerca de esta trematodiosis. Rev Mex Pediatr 68: 17-20. 
33. Hishmat MGA, 1995. Human fascioliasis in Behera province. Egypt J Med Lab Sci 4: 55-61.

34. Ruiz Blasco M, Ramia Damario M, 2014. Fasciolosis humana en lactante, a propósito de un caso. $7^{\circ}$ Congreso Argentino de Infectología Pediátrica, Foro de Sociedades de Pediatría del Cono Sur, Sociedad Argentina de Pediatría, Ciudad de Córdoba 3-5 April 2014, Programa Final y Libro de Resúmenes. RPD 132: 109.

35. Curtale F, Hassanein YAE, EI Wakeel A, Mas-Coma S, Montresor A, 2003. Distribution of human fascioliasis by age and gender among rural population in the Nile Delta, Egypt. $J$ Trop Pediatr 49: 264-268.

36. Jensenius M, Flaegstad T, Stenstad T, Gjølberg T, Vlatkovic L, Schjøth-Iversen L, Berild D, Bordmann G, Myrvang B, 2005. Fascioliasis imported to Norway. Scand $J$ Infect Dis 37: 534-537.

37. Penn Harris J, 1857. Lettre au professeur R. Owen - Liverpool 1856. Appendix B de la traduction anglaise du Manuel des parasites de Küchenmeister par Edwin Lankester - London.

38. Bhambal SS, Bhandari NR, Bajpai R, 1980. Liver-fluke infestation (Fasciola hepatica). Ind Pediatr 17: 469-471.

39. Favennec L, Jave Ortiz J, Gargala G, Lopez Chegne N, Ayoub A, Rossignol JF, 2003. Double blind, randomized, placebocontrolled study of nitazoxanide in the treatment of fascioliasis in adults and children from northern Peru. Alim Pharmacol Ther 17: 265-270.

40. Marcos LA, Maco V, Castillo M, Terashima A, Zerpa R, Gotuzzo E, 2005. Reporte de casos de fasciolosis en el Instituto Especializado de Salud del Niño Lima - Perú (1988-2003). Rev Gastroenterol Perú 25: 198-205.

41. Weil J, Golay JM, Jacquet R, 1965. Un cas de distomatose erratique à forme sous-coutanée chez un enfant de 3 ans. Arch Franç Péd 22: 567-572.

42. Auer H, Aspöck H, Picher O, Ploier R, Tulzer W, 1981. Menschliche infektionen mit Fasciola hepatica in Österreich. Wien Klin Wochenschr 93: 360-366.

43. Farid Z, Kamal M, Woody J, 1988. Treatment of acute toxaemic fascioliasis. Trans $R$ Soc Trop Med Hyg 82: 299.

44. Rokni MB, Massoud J, O'Neill SM, Parkinson M, Dalton JP, 2002. Diagnosis of human fasciolosis in the Gilan province of northern Iran: application of cathepsin L-ELISA. Diagn Microbiol Infect Dis 44: 175-179.

45. Marcos LA, Maco Flores V, Terashima A, Samalvides F, Miranda E, Tantalean M, Espinoza JR, Gotuzzo E, 2004. Hiperendemicidad de fasciolosis humana en el Valle del Mantaro, Perú: factores de riesgo de la infección por Fasciola Hepática. Rev Gastroenterol Perú 24: 158-164.

46. Domenech Cañete I, González Núñez I, González Rodríguez Z, García Cristia Y, de la Paz Bermudez T, Pino Santos A, 2011. Absceso hepático, una forma de presentación infrecuente de la fasciolosis en Cuba. Rev Panam Infectol 13: 53-56.

47. Leon JF, Diaz JO, 2016. Fasciola hepatica infections: differences in the clinical, analytical and imaging assessments. Gastroenterol Hepatol 5: 00148.

48. Alvarez-Chacón R, García-Rosales JJ, de la Cruz-Otero MC, Wong-Chío M, Cabrera-Bravo M, Gómez-Gomez JV, GamezAranda V, 1992. Fasciolosis en los niños. Estudio de 10 casos. Bol Méd Hosp Inf México 49: 365-371.

49. Paul F, 1927. Distomiasis hepatica (Leberegelseuche) beim Menschen. Mediz Klinik 22: 829-834.

50. Carani U, 1936. Un caso di distomatosi da Fasciola epatica in un bambino di 4 anni. Clin Pediatr 18: 311-316, 319-326, 329.

51. Bürgi K, 1938. Ein Fall von Leberdistomatose bei einem 4jährigen Kinde. Schweiz Mediz Wochenschr 47: 1274-1277.

52. Biagi F, Soto R, Dorantes S, Castrejon O, Portilla J, 1957. Dos casos de fasciolosis en su período inicial como problema de diagnóstico. Bol Méd Hosp Inf México 14: 533-544.

53. Hernandez-Chinas CJ, Tay J, Biagi F, 1959. Epidemia familiar de fasciolosis en la Ciudad de México. Medicina (México) 39: 529-531.

54. Fromantin M, Riberi P, Rossazza C, Carnus, 1963. Remarques sur les critères de guérison de la distomatose hépatique, traitée par la déhydro-émétine. A propos d'une épidémie familiale. Soc Méd Milit Fr 10: 425-430.
55. Aguilar FJ, Rodriguez F, Cifuentes CE, Aguilar JR, 1967-1968. Diagnostico de Fascioliasis humana en Guatemala. Rev Col Med Guatemala 18: 265, 19: 109-116.

56. Sroczyńska M, Sonta-Jakimczyk D, 1977. Diagnostic and therapeutic difficulties in a case of liver fluke infestation in a 4-yearold child [article in Polish]. Pediatr Polska 52: 777-779.

57. Smoljan I, Spiranec N, Smolic V, Ruza Bengeri M, 1990. Ectopic and hepatobiliary fascioliasis: case report of a four-year-old patient. Giorn Mal Inf Parassit 42: 606-608.

58. Yilmaz H, Öner AF, Akdeniz H, Arslan S, 1998. The effect of triclabendazole (Fasinez $®$ ) in children with fascioliasis. J Egypt Soc Parasitol 28: 497-502.

59. García Arias ML, Marugan de Miguelsanz JM, Ordoñez Bayon MJ, Costilla S, Diez Baños N, 1999. Fascioliasis hepática: un nuevo caso en la infancia. An Esp Pediatr 50: 65-67.

60. Cervantes-Islas IE, Zaldivar-Cervera J, Velazquez-Ortega J, Clemente-Ramirez L, 2002. Estenosis del esfínter de Oddi por Fasciola hepatica en un preescolar. Rev Mex Cir Pediatr 9: 105-108.

61. Yi-Zhu X, Zhi-Bang Y, 2010. A case of ectopic fascioliasis in the skin. Trop Doct 40: 253-254.

62. Hatami H, Asmar M, Masoud J, Mansouri F, Namdaritabar $\mathrm{H}$, Ramazankhani A, 2012. The first epidemic and new-emerging human fascioliasis in Kermanshah (western Iran) and a ten-year follow up, 1998-2008. Int J Prev Med 3: 266-272.

63. Periago MV, Valero MA, Panova M, Mas-Coma S, 2006. Phenotypic comparison of allopatric populations of Fasciola hepatica and Fasciola gigantica from European and African bovines using a computer image analysis system (CIAS). Parasitol Res 99: 368-378.

64. Valero MA, Santana M, Morales M, Hernandez JL, Mas-Coma S, 2003. Risk of gallstone disease in advanced chronic phase of fascioliasis: an experimental study in a rat model. $J$ Infect Dis 188: 787-793.

65. Valero MA, Navarro M, Garcia-Bodelon MA, Marcilla A, Morales M, Garcia JE, Hernandez JL, Mas-Coma S, 2006. High risk of bacterobilia in advanced experimental chronic fasciolosis. Acta Trop 100: 17-23.

66. Valero MA, Girones N, Garcia-Bodelon MA, Periago MV, Chico-Calero I, Khoubbane M, Fresno M, Mas-Coma S., 2008. Anaemia in advanced chronic fasciolosis. Acta Trop 108: 35-43.

67. Mera y Sierra R, Agramunt VH, Cuervo P, Mas-Coma S, 2011. Human fascioliasis in Argentina: retrospective overview, critical analysis and baseline for future research. Parasit Vector 4: 104.

68. Eliachar E, Tassy R, 1960. Distomatose compliquée de péritonite chez un enfant de 13 ans. Ann Pédiatrie (Paris) 42-43: 433-435.

69. Tanir G, Karaman A, Tüfekci SB, Erdogan D, Tuygun N, Özkan AT, 2011. A case of ectopic intraabdominal fascioliasis presented with acute abdomen. Turk J Gastroenterol 22: 347-350.

70. Bernheim M, Roman E, Mouriquand C, Larbre F, 1957. La distomatose à Fasciola hepatica chez l'enfant en Europe occidentale. Pédiatrie 12: 131-143.

71. Dalton JP, Robinson MW, Mulcahy G, O'Neill SM, Donnelly S, 2013. Immunomodulatory molecules of Fasciola hepatica: Candidates for both vaccine and immunotherapeutic development. Vet Parasitol 195: 272-285.

72. Girones N, Valero MA, Garcia-Bodelon MA, Chico-Calero MI, Punzon C, Fresno M, Mas-Coma S, 2007. Immune supression in advanced chronic fascioliasis: an experimental study in a rat model. $J$ Infect Dis 195: 1504-1512.

73. Valero MA, Perez-Crespo I, Chillon-Marinnas C, Khoubbane M, Quesada C, Reguera-Gomez M, Mas-Coma S, Fresno M, Gironès N, 2017. Fasciola hepatica reinfection potentiates a mixed Th1/Th2/Th17/Treg response and correlates with the clinical phenotypes of anemia. PLoS One 12: e0173456.

74. Mas-Coma S, 2020. Human fascioliasis emergence risks in developed countries: from individual patients and small epidemics to climate and global change impacts. Enferm Infecc Microbiol Clin 38: 253-256.

75. Zumaquero-Rios JL, Sarracent-Perez J, Rojas-Garcia R, RojasRivero L, Martinez-Tovilla Y, Valero MA, Mas-Coma S, 2013. Fascioliasis and intestinal parasitoses affecting schoolchildren in Atlixco, Puebla state, Mexico: epidemiology and treatment with nitazoxanide. PLoS Negl Trop Dis 7: e2553. 
76. Esteban JG et al., 2003. Hyperendemic fascioliasis associated with schistosomiasis in villages in the Nile Delta of Egypt. Am J Trop Med Hyg 69: 429-437.

77. Gonzalez LC, Esteban JG, Bargues MD, Valero MA, Ortiz P, Naquira C, Mas-Coma S, 2011. Hyperendemic human fascioliasis in Andean valleys: an altitudinal transect analysis in children of Cajamarca province, Peru. Acta Trop 120: 119-129.

78. Ubeira FM et al.,2009. MM3-ELISA detection of Fasciola hepatica coproantigens in preserved human stool samples. Am J Trop Med Hyg 81: 156-162.
79. Gandhi P, Schmitt EK, Chen CW, Samantray S, Venishetty VK, Hughes D, 2019. Triclabendazole in the treatment of human fascioliasis: a review. Trans R Soc Trop Med Hyg 113: 797-804.

80. Villegas $\mathrm{F}$ et al., 2012. Administration of triclabendazole is safe and effective in controlling fascioliasis in an endemic community of the Bolivian Altiplano. PLoS Negl Trop Dis 6: e1720.

81. Valero MA et al., 2012. Field evaluation of a coproantigen detection test for fascioliasis diagnosis and surveillance in human hyperendemic areas of Andean countries. PLoS Negl Trop Dis 6: e1812. 